\title{
A CLINICAL-PATHOLOGICAL REPORT OF EIGHT CASES OF METHYL BROMIDE POISONING
}

BY

\author{
J. H. PRAIN and G. HARVEY SM1TH
}

From the Department of Pathology, University of St. Andrews, and Royal Infirmary, Dundee

(RECEIVED FOR PUBLICATION JULY 9, 1951)

Methyl bromide, refrigerant, fumigant, and fire extinguisher, has proved a dangerous substance. Schuler demonstrated its toxic character in 1899, and von Oettingen (1946) has listed 28 fatalities and 150 non-fatal cases of methyl bromide poisoning.

On November 4, 1947, at about 8 in the evening eight boys broke bounds from an approved school in Dundee, and despite a search by the police no trace of them was found until 8.30 the next morning when two of the boys reported back to the school stating that they felt ill. Very shortly after their return one of the boys collapsed in what appeared to be a severe epileptiform seizure (Case 1). First aid treatment by the school medical officer failed to improve his condition, and he was admitted to the Royal Infirmary, Dundee. Shortly afterwards the second boy (Case 2), who had given an incoherent story of the remaining six boys being aboard a boat in the harbour, also collapsed. He had a much milder epileptiform seizure, and was also brought to the Infirmary.

The police searched again and found the other. six boys huddled together in varied degrees of unconsciousness in a small cabin aboard a disused Royal Air Force launch. These boys were also sent to the Royal Infirmary, Dundee. The police also found a recently discharged fire extinguisher of the No. 3 Air Ministry pattern which, when full, contains 69 fluid oz. of methyl bromide.

The eight cases presented a picture differing only in degree, although later some qualitative differences were appreciated.

\section{Clinical Reports}

On admission to hospital Case 1 (age 14), Case 5

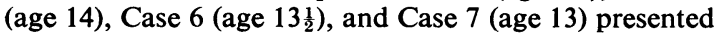
similar clinical features. All were unconscious with wide, staring eyes, a blue-grey, cold, moist skin, and had obvious signs of massive pulmonary oedema. In all the reflexes were depressed; on admission three were in convulsions, and the fourth (Case 6) developed convulsions one hour later. No urine was passed and death occurred 14 hours, one and three quarter hours, six and three quarter hours, and $14 \frac{1}{2}$ hours respectively after admission.

Case 4 (age 13) was semiconscious on admission, but suffered from marked mental confusion. The skin had a bluish-grey pallor and was cold and moist. Although the respiratory rate was 34 a minute, the lungs were clear, but three hours later loud, bubbling râles were present in all areas of the chest. Two hours later convulsions developed, and the boy died eight hours after admission. No urine was passed.

In all these cases intensive therapy-atropine, sedatives, oxygen, and stimulants-appeared to have no effect whatever on the general downhill course.

Case 8 (age $11 \frac{1}{2}$ ) was found to be dead on arrival at hospital.

The others, Cases 2 and 3, survived. Case 2 (age 13) was conscious and rational but very drowsy. The heart sounds were normal and the pulse of good volume and regular (100/min.). No adventitious sounds were heard in the lungs and respiration was quiet $(22 / \mathrm{min}$.). The reflexes were all depressed. Four hours after admission a convergent squint appeared. On admission Ringer's solution was given intravenously $(20 \mathrm{ml}$. each hour), and although by evening the patient was very restless and sweating, the lungs were still clear. Next morning, 24 hours after admission, he was feeling much better.

From the time of admission he had not passed urine but there was no evidence of distension of the bladder by percussion. Throughout the second day his condition improved, but as he remained in a state of anuria he was given 1 pint of $4.3 \%$ sodium sulphate solution intravenously. Next day he again stated that he felt much better although some puffiness of the face had developed. Eventually that afternoon, 54 hours after admission, he passed $24 \mathrm{oz}$. of urine which had a specific gravity of 1010, and contained massive amounts of albumin and granular casts. Thereafter his progress was uneventful, and he was discharged one month later apparently fully recovered and has remained healthy over a period of two years. 
A glucose tolerance test performed on the day before discharge from hospital showed a slight lowering of the renal threshold, but a urea concentration test on the following day gave satisfactory results.

The results of chemical investigations in this and Cases 1 and 3 are given in the appendix.

Case 3 (age 11) showed marked mental confusion but no other abnormal signs. He could understand simple questions and lay quietly in bed unless disturbed, when he became very noisy and restless. His colour was good, and no abnormal signs were found in the chest, respiration being normal $(22 / \mathrm{min}$.). The heart sounds were normal and the pulse was regular and of good volume. All reflexes were present but diminished. Three hours after admission his condition had deteriorated and he was very restless and confused. A few moist râles appeared in the lungs five hours later, but after a static period his condition gradually improved. The next morning breathing was a little laboured, an internal strabismus had developed, and the ophthalmologist found some pallor of the optic discs. Up to this time he had passed no urine; the bladder was not full, but there was suprapubic tenderness. Thirty-two hours after admission he passed 4 oz. of urine, which had a specific gravity of 1020 , contained considerable amounts of albumin and many granular casts with some hyaline casts and a few pus cells. For the next two days he remained drowsy but his condition improved, and he was discharged a fortnight after admission.

Four days after his admission he was talking rationally and spoke of a "dream" about being on a boat with the other boys. When seen two years after the incident, he still had no clear recollection of what had happened.

A review of the clinical features confirms the prognostic significance of generalized convulsions. The six cases developing convulsions all proved fatal. Of the two survivors one had a mild and brief epileptiform seizure, and he was obviously more ill than the boy who had no convulsive movements. Another case reported by Ramond and Lacorne (1942) recovered after convulsions, but generally their occurrence has meant a fatal outcome (Holling and Clarke, 1944; Gray, 1944).

The massive pulmonary oedema associated with the convulsions in the fatal cases made treatment difficult.

Two other important clinical points are the anuria shown by all the cases, and the delayed onset of symptoms in the boy who walked three and a half miles home (Case 1) and yet died of the poisoning.

It is of particular interest that phosgene poisoning, such as occurred in the 1914-18 war, was thought of by several clinicians experienced in chemical warfare before it was known that the boys had been exposed to a toxic vapour.

\section{Necropsy Reports}

Post-mortem examinations were carried out on five of the six fatal cases (Cases 1, 4, 5, 6, and 8).
Marked post-mortem lividity, scattered petechial haemorrhages, and cyanosis were seen in all cases with the exception of Case 5 in which no lividity was noticed. There was injection and congestion of the trachea and bronchi, numerous petechial haemorrhages being seen in Case 4, and in Case 6 the bronchi contained approximately $200 \mathrm{ml}$. of frothy fluid. Small, blood-stained bilateral pleural effusions were present in Cases 1 and 4. In the lungs there was congestion and pulmonary oedema in all the cases, and there were numerous subpleural haemorrhages most numerous in the interlobar fissures, while other discrete areas of haemorrhage were found throughout the lung substance. The liver and kidneys showed evidence of venous congestion. The meninges were congested and small subarachnoid haemorrhages were present. In one instance, Case 4, a subdural haemorrhage was present below the tentorium, lying chiefly in the left posterior fossa and passing downwards through the foramen magnum to the left side of the upper part of the spinal cord. The brain was congested, an occasional small cerebral haemorrhage was seen, and in one instance, Case 6, haemorrhage into the right choroid plexus had occurred.

During the examinations it was found that in Case 8 the right kidney showed multiple tuberculous foci with caseation, fibrosis, and in some parts calcification, while the left kidney showed one small fibrotic lesion of tuberculous type.

\section{Histological Reports}

Respiratory System.-The tracheae and bronchi were extremely congested and the submucosa seemed distended with blood-containing sinuses; the mucosa itself merely showed an occasional small area of desquamation.

The picture in the lungs varied slightly from case to case, and to a certain extent with the area of lung under observation, but there was some degree of oedema in all sections. The intense staining reaction (Fig. 1) suggested a high protein content; nonetheless there were very few cells in the fluid and certainly nothing like the pneumonic change found by Mazel, Bourret, and Roche (1946) in one of their cases. The alveolar capillaries were generally distended but there was little evidence of diffuse diapedesis and none of intracapillary thrombosis. The gross haemorrhages in the subpleural areas had curiously well-defined margins, but deeper in the lungs the edges of the haemorrhages were most diffuse.

Liver.-The liver showed acute venous congestion macroscopically, but no evidence of parenchymatous damage.

Kidneys.-The kidneys were examined in all five cases, material from two being obtained within eight hours of death. Both cases had survived between 14 and 18 hours after exposure to methyl bromide vapour. In the other three cases the necropsy was delayed by legal formalities and gross autolytic change was present.

Extreme congestion was seen in the capillaries of the cortex, and tense engorgement of the stellate veins and vasa recti. In contrast, most of the glomeruli were 


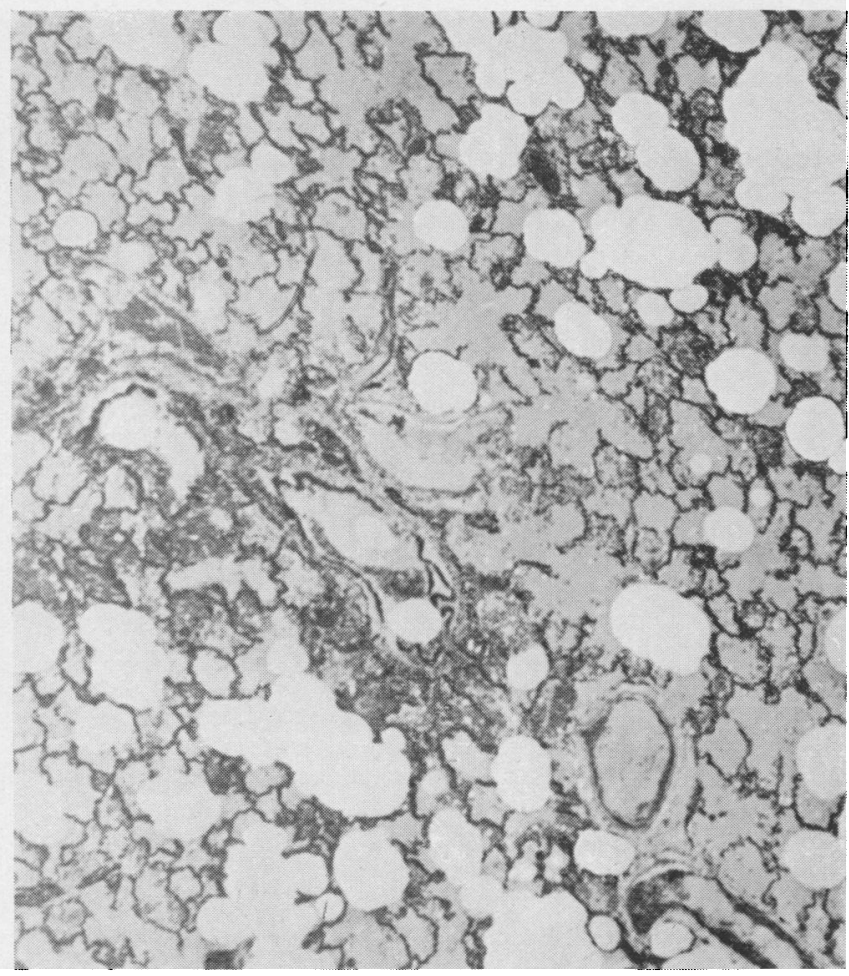

FIG. 1

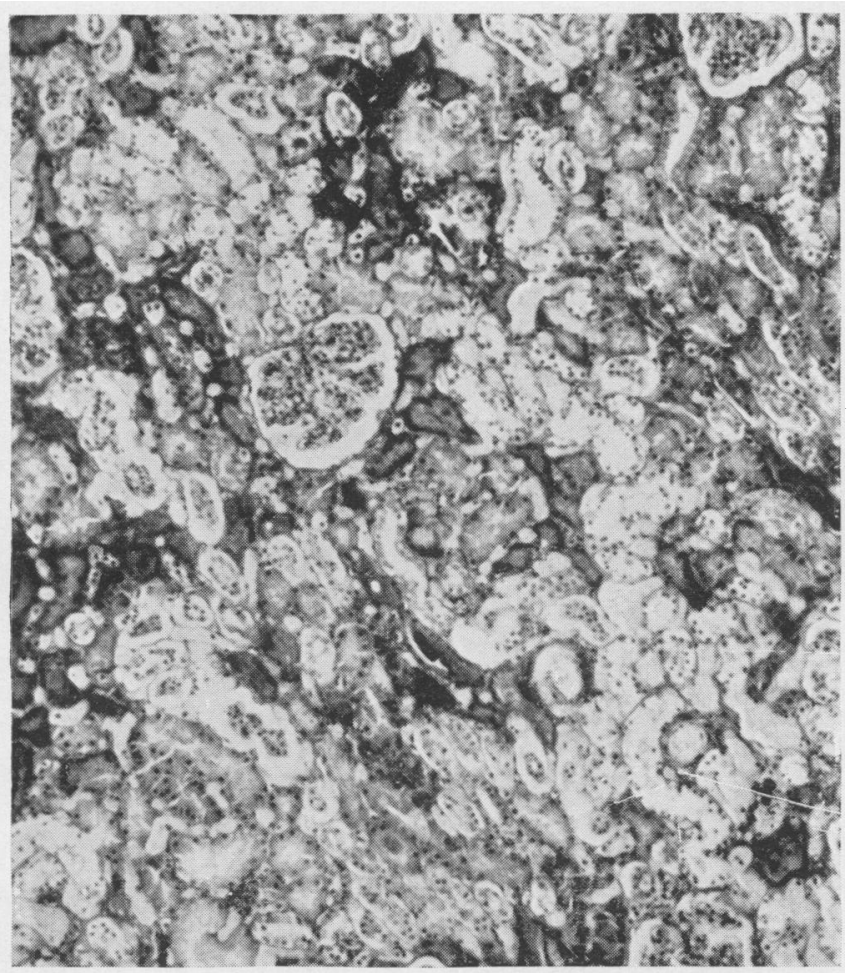

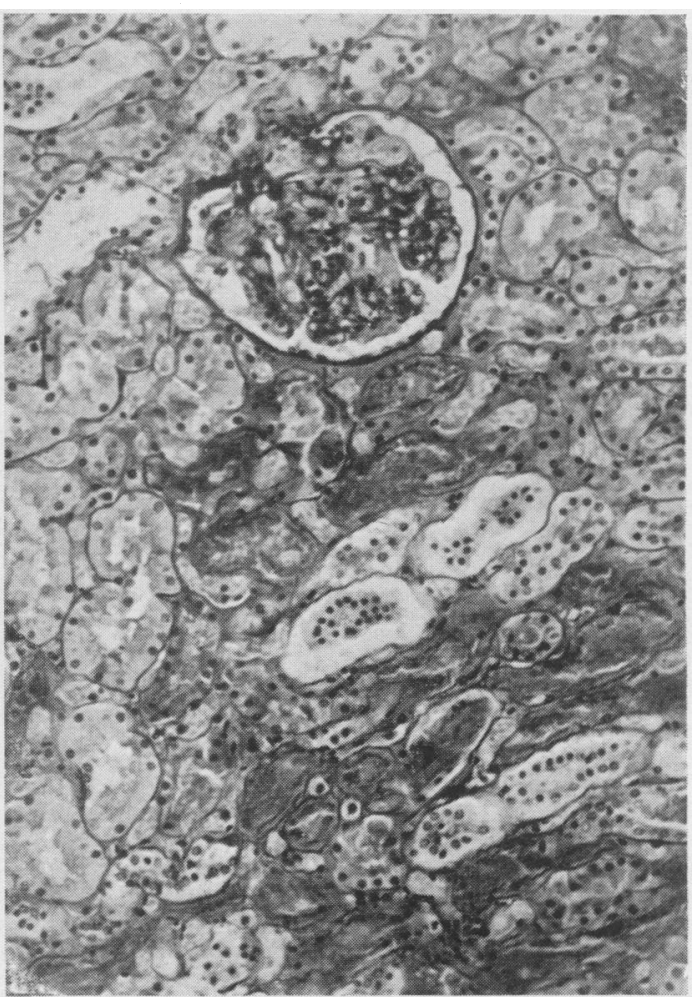

FIG. 3

FiG. 1. - In this section of lung of Case 1 there is massive pulmonary oedema, the fluid showing intense staining reaction. There is marked hyperaemia of the alveolar capillaries, some of which are tortuous and ruptured, with haemorrhages into some of the alveolj. Areas of emphysema are present. (Acid picroMallory x 92.)

Fig. 2.-In this section of renal cortex of Case 1 most of the glomeruli are normal, but the proximal convoluted tubules show complete necrosis and contain condensed granular material. The darkly staining necrotic tubules contrast sharply with the unaffected tubules. (Acid picro-Mallory x 80.)

Fig. 3.-Another section of renal cortex of Case 1 at higher magnifcation showing in greater detail the necrosis of the convoluted tubules with their content of condensed granular material. (Acid picro-Mallory x 130.)

FIG. 2 
normally collapsed, and only a few showed congestion, although some of these had blood in the glomerular spaces. In the tubules a striking lesion was observed (Figs. 2 and 3). A complete coagulative necrosis of the epithelium was present in many of the first convoluted tubules, in rather fewer of the second convoluted tubules, and in the loops of Henle, particularly the ascending limb. Many of the collecting tubules contained ribbon-like casts of condensed granular material, but no blood pigment was observed and the epithelium was intact.

\section{Discussion}

The minimum lethal dose for man of a gaseous poison can seldom be learned from accidental poisoning. On the other hand, when a group of people is involved the variation in susceptibility is often shown to be curiously wide (Duvoir, Fabre, and Layani, 1937 ; Michaux, Clercy, and Lechevallier, 1945 ; Michaex, Courchet, and Lechevallier, 1944 ; Johnstone, 1945). As far as can be ascertained the cabin door had been open before Cases 1 and 2 left to return to the school, but when the searchers arrived this door was locked and they had to force their way in. Presumably the survivor of this group (Case 3) had been exposed to the same concentration of vapour as the remainder of the party.

The delayed action of methyl bromide, similar to that of phosgene, is already known, but it is noteworthy that one boy walked three and a half miles without feeling more than vaguely ill (Case 1), then collapsed and was dead within 15 hours.

It appears that after the period of silent absorption the clinical picture depends on a threefold effect : damage to the respiratory system fairly localized to its periphery, and, like phosgene, mainly affecting the capillaries; rapid damage to the renal tubular epithelium produced either by a toxic effect of the methyl bromide (or breakdown product) or by ischaemia through its action on the renal capillaries; and thirdly a cerebral upset which, in view of the timing, can hardly be secondary to either the pulmonary or the renal upset.

In the kidneys the appearances certainly suggest a selective toxic action on the tubules, with results very similar to those described by Bywaters and Dible (1942) in "crush syndrome", although the tubular casts do not give the pink hyaline staining mentioned by these authors. This tubular damage also resembles closely the renal changes seen after excessive vomiting (McLetchie, 1943) and carbon tetrachloride poisoning (Woods, 1946; Moon, 1950). The tubulo-venous communications, originally discovered by Dunn, Gillespie, and Niven (1941) in the "crush syndrome" and since reported in the kidney after excessive vomiting and after carbon tetrachloride poisoning, were not found in our cases. It may well be that these differences are related to the time of survival. It is of course scarcely possible to say when exactly the kidney of the " crush syndrome" received its toxic dose, but the shortest case described by Bywaters and Dible (1942) survived for four days after the onset of renal symptoms. McLetchie's case survived 16 days, as did that of Woods, whereas our cases were dead within 18 hours of exposure.

The distribution of the tubular necrosis is so sharply confined to the region where changes in reaction and concentration normally occur (Dunn and others, 1941) that one might reasonably postulate a local breakdown of the methyl bromide with the formation of toxic substance. On the other hand a vascular upset could be the basis of the damage, and it may be recalled that as long ago as 1915 Oliver suggested such a mechanism in corrosive sublimate poisoning. His hypothesis was that the mercuric chloride brought about an intense vascular stasis in the kidney and an ischaemic necrosis of the tubules resulted. This latter part of his idea received some confirmation in the recent finding by Wainwright (1950) that a similar tubular necrosis follows temporary experimental occlusion of the renal artery. It seems fairly certain that in the lungs methyl bromide produces its main damaging effect on the blood vessels, and the possibility of its doing likewise in the kidneys cannot be lightly dismissed.

The anuria could be explained on the basis either of a leakage of glomerular filtrate back across the damaged tubules (Dunn and others, 1941) or of the intense stasis, although this latter seems less probable as so many of the glomeruli were apparently normal.

The development of uraemia after inhalation of methyl bromide has been described by Benatt and Courtney (1948), but there were no convulsions and recovery followed. In our cases the convulsions appeared before a true uraemia could possibly have developed, and it is reasonable to assume that their occurrence points to a direct effect on the brain as a result of greater dosage.

The late appearance of optic disturbance raised the possibility that the methyl bromide was being split in the body with the formation of methyl alcohol, but, as the survivors do not suffer from any detectable impairment of vision, it is unlikely that methyl alcohol was concerned either here or in the production of the other nervous symptoms.

\section{Summary}

The results of poisoning by the inhalation of methyl bromide are described in an incident in 
which eight boys were exposed to the vapour, six of whom died. The main clinical features and post-mortem findings are given, and a note on the survivors two years after the accident.

We wish to thank Dr. J. Morgan and Dr. J. Gordon Clark for the clinical details, Dr. G. R. Tudhope, Dr. W. Fyffe Dorward, and Dr. A. Inglis for the use of post-mortem material, and Professor A. C. Lendrum for his help throughout the study.

\section{REFERENCES}

Bywaters, E. G. L., and Dible, J. H. (1942). J. Path. Bact., 54, 111 Benatt, A. J., and Courtney, T. R. B. (1948). British Journal of Industrial Medicine, 5,21 .
Dunn, J. S., Gillespie, M., and Niven, J. S. F. (1941). Lancet, 2, 549. Duvoir, M., Fabre, R., and Layani, F. (1937). Bull. Soc. méd. Hôp. Paris, 53, 1540.

Gray, P. H. K. (1944). J. roy. nav. med. Serv., 30, 214.

Holling, H. E., and Clarke, C. A. (1944). Ibid., 30, 218.

Johnstone, R. T. (1945). Industr. Med., 14, 495.

McLetchie, N. G. B. (1943). J. Path. Bact., 55, 17.

Mazel, P., Bourret, J., and Roche, L. (1946). Arch. Mal. prof., 7, 38. Michaux, J., Clercy, A., and Lechevallier, J. (1945). Ibid., 6, 143. -, Courchet, A., and Lechevallier, J. (1944). Rev. Neurol., 76, 229. Moon, H. D. (1950). Amer. J. Path. 26, 1041.

Oliver, J. (1915) J. Amer. J. Path., 26,

Oettingen, W. F. von (1946). Publ. Hlith Bull., Wash., No. 185

Ramond, L.: and Lacorne, J. (1942). Bull. Soc. méd. Hôp. Paris, 58,158 .

Schuler (1899). Dtsch. Vjschr. öff. GesundhPff., 31, 696. Quoted by von Oettingen.

Wainwright, J. (1950). Brit. J. exp. Path., 31, 400.

Woods, W. W. (1946). J. Path. Bact., 58, 767.

\section{A P P E N D I X}

TABLE 1

LABORATORY FINDINGS IN CASE 2

\begin{tabular}{|c|c|c|c|c|c|c|c|}
\hline Date & & $\begin{array}{c}\text { Blood } \\
\text { Urea } \\
\text { (mg./100 } \\
\text { ml.) }\end{array}$ & $\begin{array}{c}\text { Blood } \\
\text { Chloride } \\
\text { (as NaCl) } \\
\text { (mg./100 } \\
\text { ml.) }\end{array}$ & $\begin{array}{l}\text { Total } \\
\text { Serum } \\
\text { Proteins } \\
\text { (g./100 } \\
\text { ml.) }\end{array}$ & $\begin{array}{l}\text { Serum } \\
\text { Albumin } \\
\text { (g. } / 100 \\
\text { ml.) }\end{array}$ & $\begin{array}{c}\text { Alkaline } \\
\text { Phosphatase } \\
\text { (K. and A. } \\
\text { units } / 100 \\
\text { ml.) }\end{array}$ & Urine \\
\hline November 5,1947 & $\cdots$ & 65 & 456 & 6 & $3 \cdot 9$ & 30 & Nil \\
\hline $6, \quad$, & $\cdots$ & 100 & 364 & $5 \cdot 8$ & $4 \cdot 1$ & 20 & Nil \\
\hline 7, & $\cdots$ & 119 & 351 & $5 \cdot 8$ & $4 \cdot 1$ & 20 & $\begin{array}{l}\text { Albumin }++++ \\
\text { Granular casts }\end{array}$ \\
\hline $8, \quad$, & $\cdots$ & 190 & 424 & 6 & 4 & 20 & $\begin{array}{l}\text { Albumin }+++ \\
\text { Granular casts }\end{array}$ \\
\hline $9, \quad$, & $\cdots$ & 200 & 468 & 6 & 4 & 16 & $\begin{array}{l}\text { Albumin }++ \\
\text { Few casts }\end{array}$ \\
\hline$, \quad 10, \quad$, & $\cdots$ & 224 & 448 & - & - & - & $\begin{array}{l}\text { Albumin } \\
\text { Epithelial casts }\end{array}$ \\
\hline$, \quad 11, \quad$, & $\cdots$ & 195 & - & - & - & 12 & - \\
\hline$, \quad 13, \quad$, & $\cdots$ & 190 & - & - & - & 7 & - \\
\hline Urea clearance. . & . & $15 \cdot 7^{*}$ & - & 一 & - & - & - \\
\hline November 15,1947 & . & 147 & - & 7 & $4 \cdot 8$ & - & 一 \\
\hline Urea clearance. . & . & $13 \cdot 1$ & - & - & - & - & - \\
\hline November 20, 1947 & . & 110 & - & - & - & - & - \\
\hline Urea clearance. . & . & $29 \cdot 8$ & - & 一 & - & - & - \\
\hline November 27, 1947 & . & 31 & 468 & 7 & $4 \cdot 8$ & 7 & Urine clear \\
\hline Urea clearance. . & . & 65 & - & 一 & - & - & - \\
\hline December 4, 1947 & $\cdots$ & 30 & 468 & $7 \cdot 1$ & $4 \cdot 8$ & 7 & - \\
\hline Urea clearance. . & . & $50 \cdot 5$ & - & - & - & - & - \\
\hline
\end{tabular}

* Van Slyke urea clearance is expressed as a percentage of average normal function 
TABLE 2

LABORATORY FINDINGS IN CASE 3

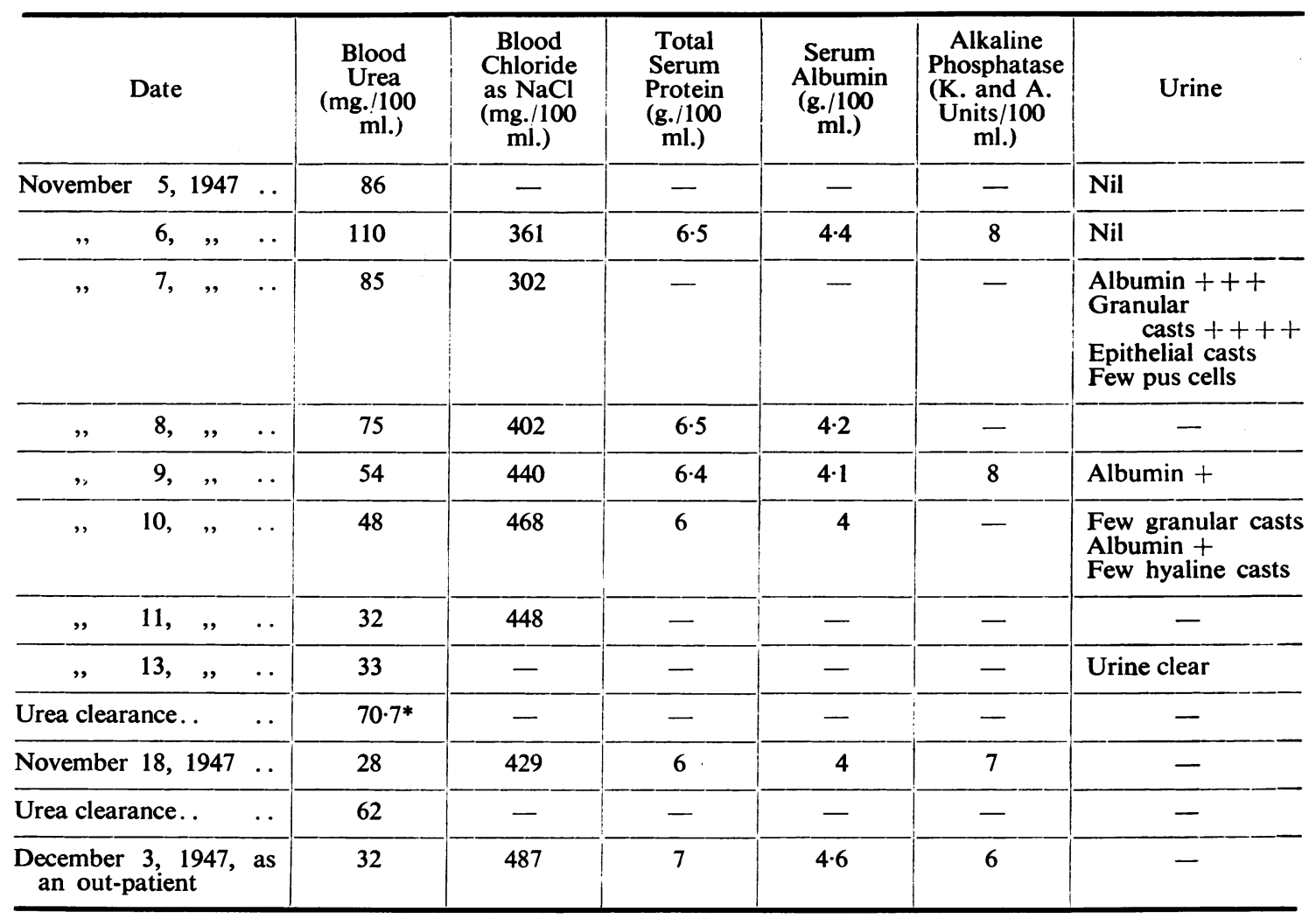

* Van Slyke urea clearance is expressed as a percentage of average normal function Note. Blood bromide estimations were not made.

The laboratory findings in Case 1 were as follows :Whole blood chlorides (as $\mathrm{NaCl}$ ) .. $370 \mathrm{mg}$. per $100 \mathrm{ml}$.
Blood urea .. $95 \mathrm{mg}$. per $100 \mathrm{ml}$.

Plasma alkaline phosphatase . . 39 units per $100 \mathrm{ml}$. (King-Armstrong units). 